\title{
Bioactive glass S53P4 eradicates Staphylococcus aureus in biofilm/planktonic states in vitro
}

\author{
Torstein Grønseth ${ }^{a, b}$, Lene K. Vestbyc, Live L. Nesse ${ }^{d}$, Magnus von Unge ${ }^{e, f}$ and Juha T. Silvola $a^{a, b, e}$ \\ ${ }^{a}$ Institute for Clinical Medicine, University of Oslo, Oslo, Norway; ${ }^{b}$ Department of Otolaryngology, Head and Neck Surgery, Oslo University \\ Hospital, Oslo, Norway; 'Department of Analysis and Diagnostic, Norwegian Veterinary Institute, Oslo, Norway; ${ }^{\mathrm{d} D e p a r t m e n t}$ of Animal

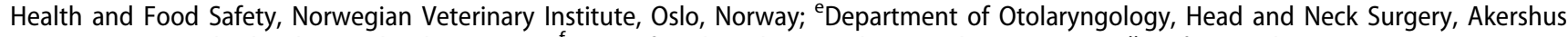 \\ University Hospital, Akershus and Oslo, Norway; ${ }^{f}$ Center for Clinical Research, Uppsala University, Västerås, Sweden
}

\begin{abstract}
Background: Increasing antimicrobial resistance to antibiotics is a substantial health threat. Bioactive glass S53P4 (BAG) has an antimicrobial effect that can reduce the use of antibiotics. The aim of this study was to evaluate the antimicrobial efficacy of BAG in vitro on staphylococci in biofilm and in planktonic form. Secondary aims were to investigate whether supernatant fluid primed from BAG retains the antibacterial capacity and if ciprofloxacin enhances the effect.

Methods: BAG-S53P4 granules, $<45 \mu \mathrm{m}$, primed in tryptic soy broth (TSB) were investigated with granules present in TSB $(100 \mathrm{mg} / \mathrm{mL})$ and after removal of granules $(100,200$, and $400 \mathrm{mg} / \mathrm{mL})$. The efficacy of BAG to eradicate Staphylococcus aureus biofilm in vitro was tested using 10 different clinical strains and 1 reference strain in three test systems: the biofilm-oriented antiseptic test based on metabolic activity, the biofilm bactericidal test based on culturing surviving bacteria, and confocal laser scanning microscopy (CLSM) combined with LIVE/DEAD staining.

Results: Exposure to $48 \mathrm{~h}$ primed BAG granules $(100 \mathrm{mg} / \mathrm{mL})$ produced bactericidal effects in $11 / 11$ strains $(p=0.001)$, and CLSM showed reduction of viable bacteria in biofilm $(p=0.001)$. Supernatant primed 14 days, $400 \mathrm{mg} / \mathrm{mL}$, reduced metabolic activity $(p<0.001)$, showed bactericidal effects for $11 /$ 11 strains $(p=0.001)$, and CLSM showed fewer viable bacteria $(p=0.001)$. The supernatant primed for $48 \mathrm{~h}$, or in concentrations lower than $400 \mathrm{mg} / \mathrm{mL}$ at 14 days, did not completely eradicate biofilm.

Conclusion: Direct exposure to BAG granules, or primed supernatant fluid, effectively eradicated $S$. aureus in biofilm. The anti-biofilm effect is time- and concentration-dependent. When BAG had reached its full antimicrobial effect, ciprofloxacin had no additional effect.
\end{abstract}

ARTICLE HISTORY

Received 15 September 2019

Revised 20 April 2020

Accepted 4 May 2020

\section{KEYWORDS}

BAG; biofilm; confocal laser scanning microscopy;

Staphylococcus aureus

\section{Introduction}

Bacteria can alternate between a planktonic and a biofilm state. As biofilm, bacteria are attached to a substratum, or to each other, and are embedded in a self-produced extracellular polymeric substance. Since the 1970s, when Nils Høiby observed a link between the aetiology of a persistent infection and aggregates of bacteria in cystic fibrosis patients (1), biofilm infections have become increasingly recognised in chronic infections. A common pathogen is Staphylococcus aureus, a potent biofilm producer (2-6). Bacteria living in biofilm display an altered antimicrobial resistance phenotype through a lower metabolic rate and a reduced rate of cell division $(7,8)$. In addition, the biofilm can act as a diffusion barrier, and also cause deactivation of antimicrobial substances (9-11). As a result, the minimum inhibitory concentration of antimicrobial compounds on bacteria in biofilm can reach 500-1000 times that of their planktonic counterparts $(9,12)$. Mature biofilm can further shed off planktonic bacteria or micro-colonies that may travel to other parts of the body, causing relapsing infections (10).

Because of these biofilm defense mechanisms and growing antimicrobial resistance $(13,14)$, we need innovative new treatments in addition to conventional antimicrobial treatment. One such option is bioactive glass (BAG), a synthetic silica-based material. BAG gradually releases ions from the granules' surfaces when in contact with biological fluids. This leads to an increase in osmotic pressure and $\mathrm{pH}$, thus making the surrounding environment unsuitable for microbial growth (15-17). There are several types of BAG with differing antibacterial activity, one of which, BAG-S53P4, has been well studied $(15,18)$. In clinical practice, BAG has been used to fill bone cavities (19) and treat osteomyelitis in orthopaedic surgery (20), chronic frontal sinusitis during frontal sinus obliteration (21), and chronic otitis media during mastoid obliteration $(22,23)$. The diameter of the granules is usually between $0.5 \mathrm{~mm}$ and $3.15 \mathrm{~mm}$. 
The main aim of the study was to evaluate the antimicrobial efficacy of BAG-S53P4 in vitro on clinical strains of S. aureus in biofilm and planktonic form. The sub-aims were to investigate whether the supernatant fluid primed from BAG retained anti-biofilm properties after removal of the granules, and to evaluate whether addition of ciprofloxacin causes an increased anti-biofilm effect.

\section{Methods}

\section{Study design}

Ten clinical strains of $S$. aureus and one reference collection strain were first studied to verify their biofilm-producing capacity. The 11 bacterial strains were then tested in a planktonic state for sensitivity to BAG (broth dilution test) and ciprofloxacin (disc diffusion test). If a strain was not sensitive in the planktonic state, it was excluded from further tests in the biofilm form. The antimicrobial effect on bacteria living in biofilm in vitro was then tested using three different methods: biofilm-oriented antiseptic test (BOAT); biofilm bactericidal test; and confocal laser scanning microscopy (CLSM).

\section{Bacterial strain collection and verification}

Ten clinical strains of $S$. aureus were collected from 10 randomly selected unique individuals with draining ears at Oslo University Hospital, in a period from April to October 2014. S. aureus ATCC 29213, a previously described strain known for its biofilm-producing capabilities, was used as a positive control $(24,25)$. The strains from the draining ears were obtained by using an otomicroscope and a sterile swab (VWR transport swabs, Copan, Breschia, Italy). The identification and antibiotic susceptibility testing did not reveal any MRSA strains (MALDI-TOF-MS, Bruker Daltonik GmbH, Bremen, Germany; VITEK ${ }^{\circledR}$ 2, bioMérieux S.A. France). The bacteria were stored in a freezing broth at $-70^{\circ} \mathrm{C}$ (Frysebuljong, Oslo University Hospital, Oslo, Norway). Before the tests, each strain was plated onto blood agar plates (Blod agar plater, Oslo University Hospital, Oslo, Norway) for amplification and verification of purity. The blood agar plates were incubated for $24 \mathrm{~h}$ at $37 \pm 1^{\circ} \mathrm{C}$.

\section{Test substance}

Our study evaluated the antimicrobial efficacy of smaller granules of BAG-S53P4, $<45 \mu \mathrm{m}$, (donated by BonAlive Biomaterials, Turku, Finland), which have previously been shown to have greater antimicrobial activity compared with larger-sized granules (16). The concentrations and exposure times used are shown in Table 1. The concentrations were selected based on our broth dilution test and on previous studies (26).

The test substance was obtained by adding BAGS53P4 $<45 \mu \mathrm{m}$ to tryptic soy broth (TSB) with $1 \%$ glucose/ $1 \%$ $\mathrm{NaCl}, \mathrm{pH} 7.0$, and vortexed (60 s) to ensure that all granules were in contact with the broth. The test substances were placed at room temperature prior to the experiment. One
Table 1. Test substance and exposure time.

\begin{tabular}{lc}
\hline Test substance & Priming time \\
\hline BAG-S53P4 $<45 \mu \mathrm{m}, \mathrm{TSB}$ with $1 \%$ glucose $/ 1 \% \mathrm{NaCl}$ & \\
Granule test & \\
BAG - TSB, $100 \mathrm{mg} / \mathrm{mL}$ & 2 days \\
Supernatant test & \\
BAG - TSB, $100 \mathrm{mg} / \mathrm{mL}$ & 2 days \\
BAG - TSB, $200 \mathrm{mg} / \mathrm{mL}$ & 2 days \\
BAG - TSB, $400 \mathrm{mg} / \mathrm{mL}$ & 2 days \\
BAG - TSB, $100 \mathrm{mg} / \mathrm{mL}$ & 14 days \\
BAG - TSB, $200 \mathrm{mg} / \mathrm{mL}$ & 14 days \\
BAG - TSB, $400 \mathrm{mg} / \mathrm{mL}$ & 14 days \\
BAG - TSB, $100 \mathrm{mg} / \mathrm{mL}$ with ciprofloxacin $5 \mu \mathrm{g} / \mathrm{mL}$ & 2 days \\
BAG - TSB, $200 \mathrm{mg} / \mathrm{mL}$ with ciprofloxacin $5 \mu \mathrm{g} / \mathrm{mL}$ & 2 days \\
BAG - TSB, $400 \mathrm{mg} / \mathrm{mL}$ with ciprofloxacin $5 \mu \mathrm{g} / \mathrm{mL}$ & 2 days \\
BAG - TSB, $100 \mathrm{mg} / \mathrm{mL}$ with ciprofloxacin $5 \mu \mathrm{g} / \mathrm{mL}$ & 14 days \\
BAG - TSB, $200 \mathrm{mg} / \mathrm{mL}$ with ciprofloxacin $5 \mu \mathrm{g} / \mathrm{mL}$ & 14 days \\
BAG - TSB, $400 \mathrm{mg} / \mathrm{mL}$ with ciprofloxacin $5 \mu \mathrm{g} / \mathrm{mL}$ & 14 days \\
$\mathrm{pH}$-adjusted (NaOH) TSB with $1 \%$ glucose $/ 1 \% ~$ & $\mathrm{NaCl}$ \\
$\mathrm{pH}$-adjusted TSB, pH 7.0 & \\
$\mathrm{pH}$-adjusted TSB, $\mathrm{pH} 9.7$ & \\
$\mathrm{pH}$-adjusted TSB, $\mathrm{pH} 10.7$ & \\
$\mathrm{pH}$-adjusted TSB, $\mathrm{pH} 11.7$ & \\
\hline Al &
\end{tabular}

All TSB with $1 \%$ glucose $/ 1 \% \mathrm{NaCl}$ solutions were from the Norwegian Veterinary Institute, Oslo, Norway.

BAG: bioactive glass; TSB: tryptic soy broth.

test substance was prepared for $48 \mathrm{~h}$, and one 14 days prior to the test day. The time that the TSB was exposed to the BAG granules prior to test day is called priming time.

On the test day, the 48-h solutions were further divided into one group with granules (Granule contact test) and one group with only the supernatant (Supernatant test). The 14day solutions were only tested in the supernatant form (Supernatant test) (Table 1).

\section{Granule contact test}

Only $100 \mathrm{mg} / \mathrm{mL}$ BAG primed for $48 \mathrm{~h}$ was tested because of its complete eradication of biofilm at this concentration.

\section{Supernatant test}

BAG granules were removed from the test solutions, and only the supernatant was used for further testing. It was divided into two sub-tests: i) addition of ciprofloxacin; and ii) without added ciprofloxacin. The concentration of ciprofloxacin was $0.5 \mu \mathrm{g} / \mathrm{mL}$, based on a previously published study on the expected concentration of ciprofloxacin in the middle ear mucosa (27). No comparisons were made between the efficacy of BAG + ciprofloxacin and BAG alone for the concentrations of 14-day primed $400 \mathrm{mg} / \mathrm{mL}$ and $200 \mathrm{mg} / \mathrm{mL}$. The reason is that the bactericidal test for BAG alone showed 0 strains $(400 \mathrm{mg} / \mathrm{mL})$ and 3 strains $(200 \mathrm{mg} / \mathrm{mL})$ surviving of the total 11 strains.

TSB (with $1 \%$ glucose/1\% $\mathrm{NaCl}$ ) broth was $\mathrm{pH}$-adjusted with $\mathrm{NaOH}$, to $\mathrm{pH} 9.7,10.7$, and 11.7 and used as controls to similar pH-level BAG. The $\mathrm{pH}$ was chosen as a result of the highest measured $\mathrm{pH}$ from the BAG in TSB for 14 days. All $\mathrm{pH}$ measurements used a pH metre (inoLab ${ }^{\circledR} \mathrm{pH} 7310 \mathrm{P}$, WTW $\mathrm{GmbH}$, Weilheim, Germany). 


\section{Disc diffusion susceptibility testing of ciprofloxacin}

Each of the strains of the $S$. aureus was tested in its planktonic state to evaluate the efficacy of ciprofloxacin by a disc diffusion test according to the EUCAST disc diffusion method, version 5. Single colonies from a fresh overnight bacterial culture on blood agar were collected and transferred into sterile saline. The suspension was measured to McFarland 0.5 and the spread on Müller Hinton agar plates using an automated plate spreader. Diffusion discs (CIP 5, Sensi-Disc ${ }^{\mathrm{TM}}, \mathrm{BBL}^{\mathrm{TM}}$, Discs, Becton, Dickinson and Company, Sparks, MD, USA) with ciprofloxacin $5 \mu$ g were applied to the agar plates. Inhibition zones were evaluated with callipers after $18 \mathrm{~h}$ of incubation at $36 \pm 1{ }^{\circ} \mathrm{C}$.

\section{Broth dilution test for planktonic bacteria}

A modified broth dilution test was employed to evaluate the efficacy of BAG on planktonic-state bacterial strains (28). First, 48-h suspensions of TSB with BAG were made at concentrations of $50,100,200$, and $400 \mathrm{mg} / \mathrm{mL}$, separately. Two test sets were prepared for the granule contact and supernatant test. In the granule test, further tests were carried out with the BAG granules in the test solution. In the supernatant test, the supernatant of the primed fluid was pipetted into new sterile tubes without the granules for further testing.

\section{Bacterial preparation}

McFarland standard 0.5 turbidity suspensions of $1 \times 108$ colony-forming units $(\mathrm{cfu}) / \mathrm{mL}$ in sterile saline were prepared from 24-h agar incubations of pure cultures from each bacterial strain. The McFarland 0.5 solutions were then diluted in sterile 48-h primed test solution as described above to reach the standard inoculum of $5 \times 105 \mathrm{cfu} / \mathrm{mL}$. In the granule test, the supernatant fluid was first moved into new test tubes. In the new test tubes the desired inoculum concentration was reached. Thereafter the supernatant with the inoculum was transferred back to the original test tubes with the BAG. In the supernatant test, the supernatant of the primed fluid was pipetted into new sterile tubes without granules. From the supernatant the described inoculum concentration was prepared, and $200 \mu \mathrm{L}$ of bacterial inoculum with different primed supernatant concentrations was transferred in triplets to a sterile 96-well microtiter plate (Nunclon Delta Surface, Thermo Fisher Scientific, Roskilde, Denmark). Prepared samples were used within $30 \mathrm{~min}$ of preparation. Sterility control with broth only and each concentration of TSB/BAG were included in all experiments. Each bacterial strain was grown in TSB to provide a positive growth control. The test tubes for the granule test and the microplates for the supernatant test were kept at $35 \pm 1{ }^{\circ} \mathrm{C}$ for about $20 \pm 0.5 \mathrm{~h}$ before being visually evaluated for growth or no growth (28).

\section{Biofilm assay}

The ability of the $S$. aureus strains to form biofilm was tested in a 96-well microtiter plate (Nunclon Delta Surface) according to a previously published method (29). One colony of each bacterial strain was inoculated in $5 \mathrm{ml}$ of TSB, which was cultured overnight at $37 \pm 1{ }^{\circ} \mathrm{C}$. The next day, $180 \mu \mathrm{L}$ of TSB with $1 \%$ glucose $/ 1 \% \mathrm{NaCl}$ was transferred to each of the wells on the microtiter plate, except for the first three blank control wells, where $200 \mu \mathrm{L}$ was transferred. The overnight cultures were then vortexed for $40 \mathrm{~s}$, and $20 \mu \mathrm{L}$ was transferred to all the wells, except for the blank control. Each strain of the $S$. aureus was tested in three parallel wells. The microtiter plate was incubated at $37 \pm 1{ }^{\circ} \mathrm{C}$ for $48 \mathrm{~h}$. The wells were then washed three times with $220 \mu \mathrm{L}$ of tap water and left to dry at room temperature for $30 \mathrm{~min}$. After drying, $220 \mu \mathrm{L}$ of crystal violet (1\% solution, Sigma Aldrich, St Louis, MO, USA) was added and incubated for $30 \mathrm{~min}$. The wells were washed five times with $220 \mu \mathrm{L}$ of tap water. To extract the crystal violet from the biofilm, $220 \mu \mathrm{L}$ of ethanol:acetone (70:30 w:w) was added. The results were calculated by measuring the optical density at $570 \mathrm{~nm}$ (Siemens BEP 2000 Advance, Germany). The experiment was repeated three times.

\section{Biofilm-oriented antiseptics test (BOAT)}

In the presence of viable metabolically active bacteria, tetrazolium chloride (TTC) is reduced from a colourless compound to red formazan, which correlates to the number of viable cells (30-32), utilised in the BOAT method (33).

Ten clinical strains of $S$. aureus and the reference collection strain S. aureus ATCC 29213 were tested. The same 96well microtiter plate was used as in the biofilm assay and the biofilm was produced as described above with 12 parallel wells for each strain. After $48 \mathrm{~h}$ of incubation, the wells were washed with $220 \mu \mathrm{L}$ sterile $0.85 \% \mathrm{NaCl}$, before adding the active or control substances. The microtiter plate was incubated at $37 \pm 1{ }^{\circ} \mathrm{C}$ for $24 \mathrm{~h}$. For each strain, three parallel wells were exposed to BAG at concentrations of $400 \mathrm{mg} / \mathrm{mL}$, $200 \mathrm{mg} / \mathrm{mL}$, and $100 \mathrm{mg} / \mathrm{mL}$. Three wells were used as controls. The content in all wells was then removed and Dey Engley neutralising broth was added for $5 \mathrm{~min}$. The wells were filled with $200 \mu \mathrm{L}$ of TSB:TTC in the ratio of 20:1. The microtiter plate was incubated at $37 \pm 1{ }^{\circ} \mathrm{C}$ for $7.5 \mathrm{~h}$. The results were evaluated visually by colour change and measured calorimetrically. The amount of formazan produced was calculated calorimetrically by measuring the optical density at $492 \mathrm{~nm}$ (Siemens BEP 2000 Advance, Germany). The experiment was repeated three times (34).

\section{Biofilm bactericidal test}

To confirm the eradication effects of BAG solutions on staphylococcus biofilm, a model described by T. Mah was used, modified for staphylococci (33). All 11 strains were tested. The first steps of establishing a biofilm, and applying the test solution, sterile $0.85 \% \mathrm{NaCl}$, and neutralising broth 
were identical to those of the BOAT method described above and as described in our previous study (34). However, instead of then adding TSB:TTC, $200 \mathrm{ml}$ of TSB was added to each well and incubated at $37 \pm 1^{\circ} \mathrm{C}$ for $24 \mathrm{~h}$. Of the overnight culture $5 \mathrm{ml}$ was transferred from each well onto a blood agar plate and incubated at $37 \pm 1^{\circ} \mathrm{C}$ for $24 \mathrm{~h}$ before the results were evaluated visually. If there was no growth, the tested substance was considered bactericidal. The experiment was repeated three times.

\section{Confocal laser scanning microscopy (CLSM)}

The first steps of making biofilm, applying test solutions, and adding neutralising broth were identical to those of the BOAT method described above, except that a Lab-Tek II Chambered Coverglass with cover 8-well (Thermo Fisher Scientific, Inc., Waltham, MA, USA) was used instead of a microtiter plate. The slides were stained with Filmtracer $^{\mathrm{TM}}$ LIVE/DEAD ${ }^{\circledR}$ Biofilm Viability Kit, (Molecular Probes, Thermo Fisher Scientific, Inc., Waltham, MA, USA) according to the manufacturer's specifications. Images of the stained biofilm were generated on a CLSM (Zeiss LSM710, Germany). A $488 \mathrm{~nm}$ argon laser line was used for the SYTO ${ }^{\circledR} 9$ and a $561 \mathrm{~nm}$ DPSS laser line for the propidium iodide. The ratio of dead or dying cells to the total number of cells in the biofilm was determined by ImageJ software (open source, public domain). The experiment was repeated twice.

\section{Statistical analysis}

Statistical analyses were performed using SPSS statistical software (release 25.0 SPSS Inc., Chicago, II, USA, and STATA MP/ 15.1, StataCorp, College Station, TX, USA). $p<0.05$ was considered to be statistically significant.

In the BOAT, paired $t$ test was performed to identify any significant differences between the test substance groups compared to the controls. In the bactericidal test, a McNemar asymptotic test (using STATA MP/15.1) was performed to identify any significant differences between the test substance groups compared to the controls.

In CLSM, significant difference between the treated groups and control was calculated by paired $t$ test.

\section{Approval}

The collection of specimens from human subjects was approved by the regional ethical committee (2014/1956, REK sør-øst C).

\section{Results}

\section{Disc diffusion susceptibility testing of ciprofloxacin}

Ciprofloxacin showed clear inhibition zones $\geq 21 \mathrm{~mm}$ in the disc diffusion tests, indicating sensitive bacteria for all strains, except strain 3, which was not used for further testing with ciprofloxacin.

\section{Broth dilution test for planktonic bacterial strains}

A BAG concentration of $50 \mathrm{mg} / \mathrm{mL}$ showed growth for all strains $(11 / 11)$ in both the granule and the supernatant tests. In the test with BAG granules, $100 \mathrm{mg} / \mathrm{mL}$, there was no growth for any strains $(p=0.001)$, but the supernatant test, $100 \mathrm{mg} / \mathrm{mL}$, showed growth in $9 / 11$ strains $(p=0.160)$. The concentrations of 200 and $400 \mathrm{mg} / \mathrm{mL}$ of BAG showed no growth for any of strains $(p=0.001)$ in either test.

\section{Biofilm assay}

All strains of staphylococci grew biofilm within $48 \mathrm{~h}$ in 96well microtiter plates. Mean optical density \pm 1 SD of biofilm produced by $11 \mathrm{~S}$. aureus stains was $1.864 \pm 0.945$. The minimum optical density was 0.851 , and the maximum optical density was 3.00 .

\section{Biofilm-oriented antiseptics test (BOAT)}

BOAT was only performed in supernatants, since it was impossible to remove the BAG granules before measuring optical density, thus giving a misleading optical density. The reduction in optical density as an indirect measure of metabolic activity was significant for all concentrations of the test solutions primed for 14 days. After $48 \mathrm{~h}$ of priming only the $400 \mathrm{mg} / \mathrm{mL}$ concentration showed a significant reduction (Table 2). The optical densities in the 14-day primed test at $400 \mathrm{mg} / \mathrm{mL}$ and $200 \mathrm{mg} / \mathrm{mL}$ concentrations were similar to the blank control, while the other concentrations and durations showed some metabolically active bacteria in biofilm (Table 2). This was also observed visually, where all wells treated with the $400 \mathrm{mg} / \mathrm{mL}$ concentration for 14 days appeared blank (Figure 1). The wells exposed to other test concentrations produced different shades of red, which indicated surviving metabolically active bacteria for at least some of the strains.

A pH-adjusted TSB solution was used as a control and shown to have a significant effect on the reduction of staphylococcal metabolic activity at $\mathrm{pH} 11.7$ and 10.7, but not $\mathrm{pH}$ 9.7. All wells were completely blank with no visible shades of red colour only for the highest $\mathrm{pH}$ of 11.7.

The efficacy of BAG in the supernatant test was performed with and without ciprofloxacin. The tests showed an additional reduction of viable bacteria with ciprofloxacin only in concentrations of $100 \mathrm{mg} / \mathrm{mL}(p=0.005)$ and $200 \mathrm{mg} / \mathrm{mL}$ primed for $48 \mathrm{~h}(p=0.001)$. There was no additional effect of ciprofloxacin at any concentration of the supernatants primed for 14 days.

\section{Biofilm bactericidal test}

In the granule test, all 11 strains of staphylococci biofilm were eradicated. In the supernatant tests, no bactericidal effects were recorded for the 48-h primed 100 and $200 \mathrm{mg} /$ $\mathrm{mL}$ or the 14-day primed $100 \mathrm{mg} / \mathrm{mL}$. In the supernatant test, only the 14-day primed $400 \mathrm{mg} / \mathrm{mL}$ concentration eradicated all strains (Table 2). For the remaining concentrations 


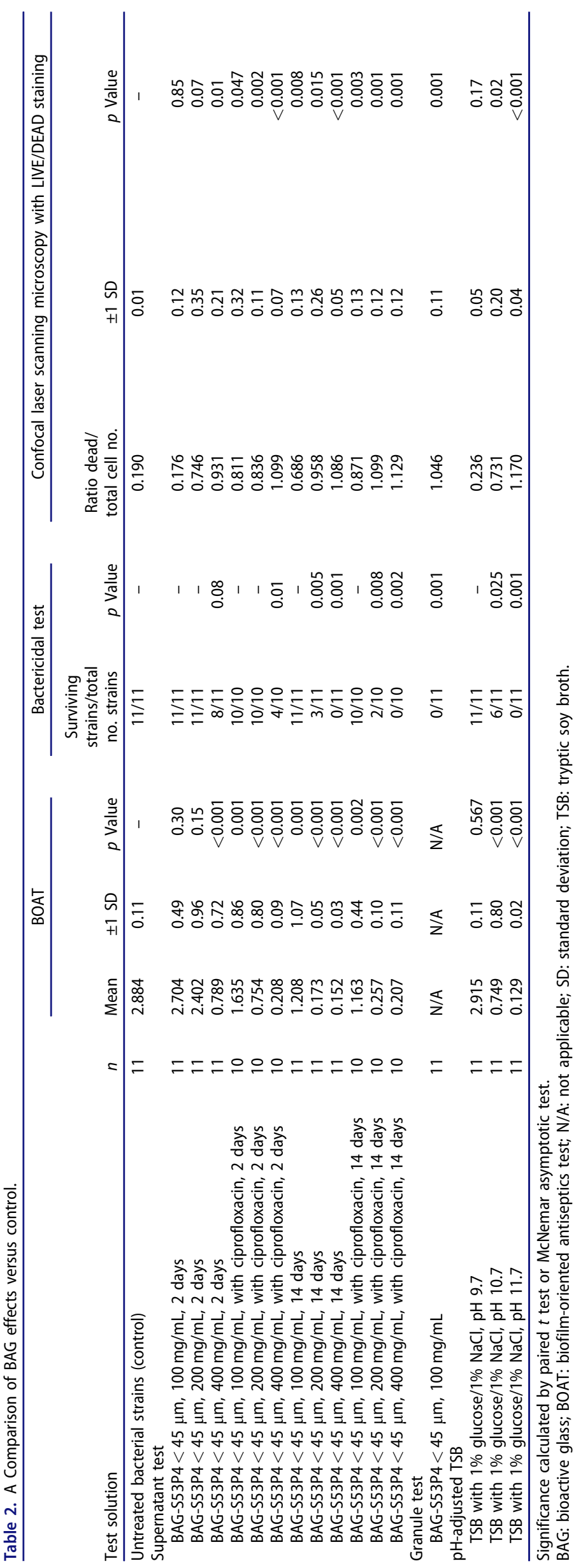


(a)

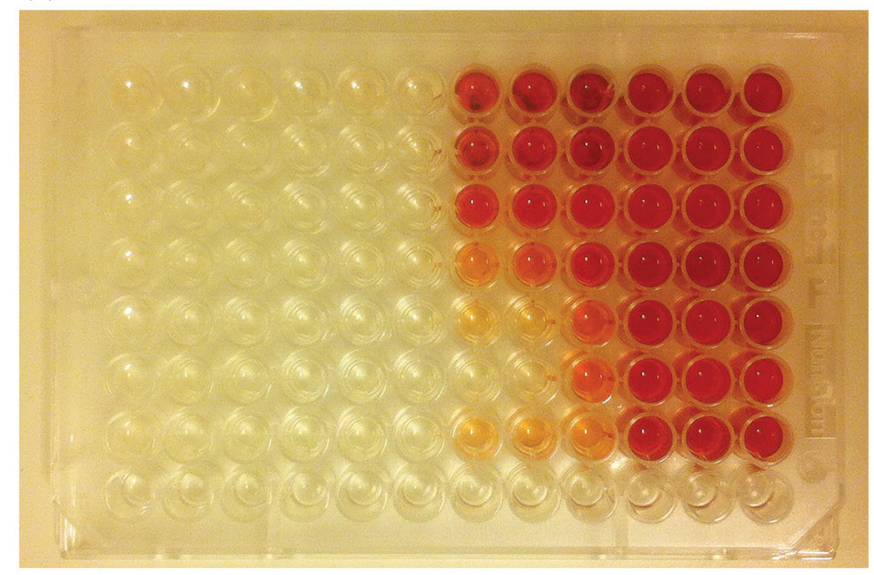

(b)

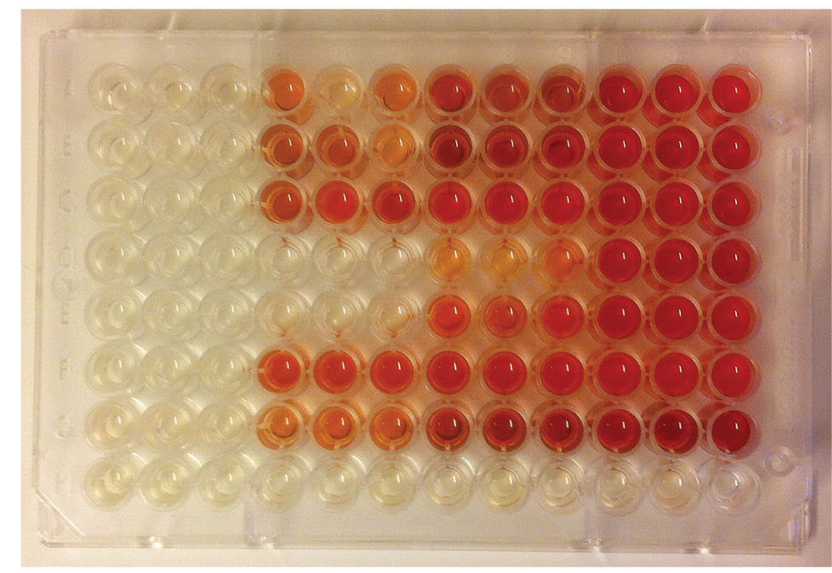

Figure 1. Biofilm-oriented antiseptics test (BOAT). Supernatant test: BAG 14-day priming time (a); BAG 2-day priming time (b). BAG concentration from left to right is $400 \mathrm{mg} / \mathrm{mL}, 200 \mathrm{mg} / \mathrm{mL}, 100 \mathrm{mg} / \mathrm{mL}$, and $0 \mathrm{mg} / \mathrm{mL} ; 3$ wells per concentration. Rows 1-7: strains 1-7; row 8: negative control. Red formazan is a sign of viable cells. (96-well microtiter plate; Nunclon Delta Surface, Thermo Fischer Scientific).

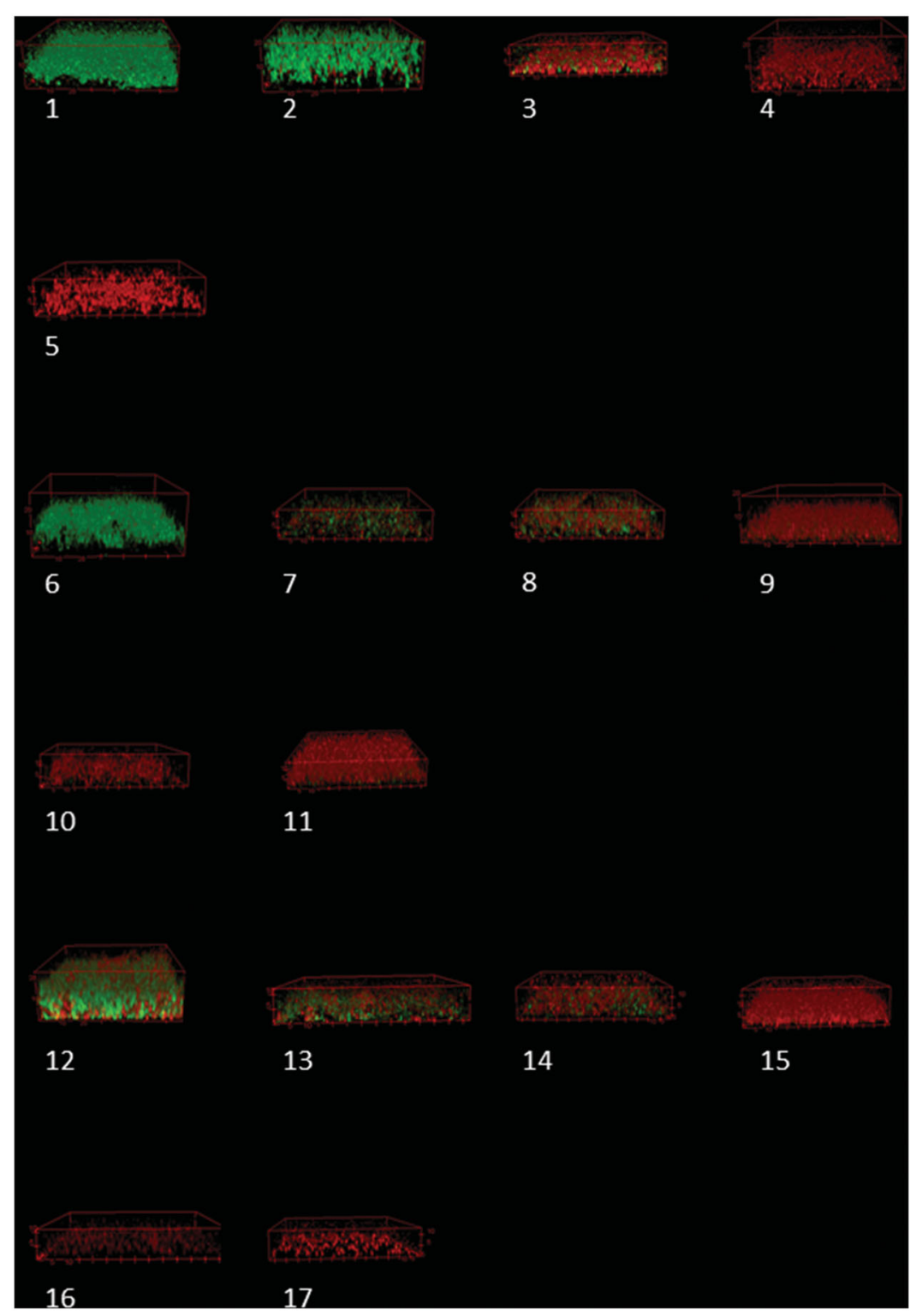

Figure 2. Confocal laser scanning microscopy (CLSM) stacks of Staphylococcus aureus biofilm. 1) Control; pH-adjusted TSB: 2) pH 9.7; 3) pH 10.7; 4) pH 11.7; 5) Granule test; Supernatant test, 2-day exposure: 6) $100 \mathrm{mg} / \mathrm{mL}$; 7) $100 \mathrm{mg} / \mathrm{mL}$ with ciprofloxacin; 8) $200 \mathrm{mg} / \mathrm{mL}$; 9) $200 \mathrm{mg} / \mathrm{mL}$ with ciprofloxacin; 10) $400 \mathrm{mg} / \mathrm{mL}$; 11) $400 \mathrm{mg} / \mathrm{mL}$ with ciprofloxacin; Supernatant test, 14-day exposure: 12) $100 \mathrm{mg} / \mathrm{mL}$; 13) $100 \mathrm{mg} / \mathrm{mL}$ with ciprofloxacin; 14$) 200 \mathrm{mg} / \mathrm{mL}$; 15) $200 \mathrm{mg} / \mathrm{mL}$ with ciprofloxacin; 16) $400 \mathrm{mg} / \mathrm{mL}$; 17) $400 \mathrm{mg} / \mathrm{mL}$ with ciprofloxacin. The units are in $\mu \mathrm{m}$. 
and durations, there was a significant bactericidal effect, but not complete eradication for all strains (Table 2). There was an additional effect of ciprofloxacin in the bactericidal test only with $400 \mathrm{mg} / \mathrm{mL}, 48-\mathrm{h}$ primed ( $p=0.046$ ). Ciprofloxacin showed no additional bactericidal effect for the other concentrations.

\section{Confocal laser scanning microscopy (CLSM)}

In the granule test, the ratio of compromised cells to the total number of cells was close to 1 , indicating that all bacteria were dead or dying (Table 2; Figure 2). In the supernatant test, there was a reduction in the 48-h primed solutions only for the concentration of $400 \mathrm{mg} / \mathrm{mL}$ (Table 2; Figure 2). Some viable biofilm bacteria were still observed. There was a significant reduction in viable cells for all concentrations primed for 14 days. The ratio of dead to total number of cells was close to 1 only for the concentrations of 200 and $400 \mathrm{mg} / \mathrm{mL}$ (Table 2). CLSM showed an additional effect of ciprofloxacin only in the group with $100 \mathrm{mg} / \mathrm{mL}$ (48 $\mathrm{h}$ primed).

\section{Summary of results}

- BAG granules $(100 \mathrm{mg} / \mathrm{mL})$ eradicated Staphylococci aureus in planktonic form.

- BAG supernatant $(200 \mathrm{mg} / \mathrm{mL})$ eradicated Staphylococci aureus in planktonic form.

- BAG granules $(100 \mathrm{mg} / \mathrm{mL})$ eradicated Staphylococci aureus in biofilm in the biofilm bactericidal test.

- BAG supernatant $(400 \mathrm{mg} / \mathrm{mL})$ primed for 14 days eradicated Staphylococci aureus in biofilm in the biofilm bactericidal test.

- BOAT tests showed that there was a reduction in metabolic activity for all concentrations after 14-day priming, but only for the $400 \mathrm{mg} / \mathrm{mL}$ concentration after $48 \mathrm{~h}$ priming.

- BAG granules $(100 \mathrm{mg} / \mathrm{mL})$ showed reduction in viable bacteria in biofilm on CLSM.

- BAG supernatant showed reduction in viable bacteria in biofilm for all concentrations primed for 14 days, and for $400 \mathrm{mg} / \mathrm{mL}$ primed for $48 \mathrm{~h}$ on CLSM.

- Ciprofloxacin had an additional effect only with a $48 \mathrm{~h}$ priming time.

\section{Discussion}

Several studies have indicated a difference in the antimicrobial sensitivity of laboratory and clinical strains (35-37). The strength of the present study is the relatively large number of clinically relevant strains compared to previous studies, and the use of three separate test systems. All three tests showed significant antibacterial properties exhibited by BAG against staphylococci in biofilm and in planktonic states. Our results show that primed BAG granules in direct contact with biofilm eradicate all viable bacteria even at the lowest concentration and shortest priming time. This indicates that BAG is a potent anti-biofilm substance.
Previous studies have indicated that small granules have a significantly stronger antimicrobial effect, and reach a higher $\mathrm{pH}$ in solution, compared with larger granules, supposedly because of a greater surface area (16). Therefore we used the smallest available granules (BAG-S53P4, <45 $\mu \mathrm{m}$ ). Our results support the use of small granule size to rapidly gain full antimicrobial effect.

It is of great interest to know if the supernatant fluid primed with granules retains its antimicrobial and anti-biofilm properties after physical removal of the granules. To our knowledge, this has not been previously investigated for staphylococcal biofilms. The results show that the surrounding fluid itself assumes anti-biofilm properties after long enough priming, even when isolated from the physical granules. Complex bone cavities, such as the mastoid cell system, are often difficult to surgically pack, and may have pockets that remain incompletely filled with granules despite efforts to pack them completely. Therefore it is important to know whether the supernatant has the same effect as granules. When the supernatant from the lowest concentration and 48-h priming time was tested, there was no reduction in viable biofilm (Table 2). The same concentration with 14-day priming resulted in reduction in viable biofilm bacteria when using CLSM and BOAT. However, only the supernatant from the concentration of 14-day primed $400 \mathrm{mg} / \mathrm{mL}$ BAG eradicated all the biofilm bacteria strains in all three test systems. This shows that the anti-biofilm effect on biofilm-associated staphylococci is dependent on concentration and priming time and that it could be beneficial to use pre-primed saline solution. This can be of importance when packing chronically infected bone cavities with biofilm-associated staphylococci.

Ciprofloxacin, which has good penetration into biofilms (38), was evaluated regarding possible additional antimicrobial effect when combined with BAG. CLSM and BOAT showed a significant reduction in viable bacteria in biofilm by combining BAG and ciprofloxacin for the two lowest concentrations primed for $48 \mathrm{~h}$, compared with BAG only (Table 2). However, the combination did not show complete bactericidal effects. This indicates that the addition of ciprofloxacin to a BAG treatment could render some additional antimicrobial effect, which could be clinically beneficial during the first days of treatment before BAG reaches its maximal effect on biofilm-associated bacteria.

The antibacterial properties of BAG have been attributed to its high $\mathrm{pH}$ and osmotic effects caused by the nonphysiological concentration of dissolved ions (39). Pre-adjusted $\mathrm{pH}$-buffered $(\mathrm{NaOH})$ TSB broth was used as a control to compare with BAG at similar $\mathrm{pH}$. The most alkaline control was set to $\mathrm{pH} 11.7$, the same as achieved by BAG primed for 14 days at $400 \mathrm{mg} / \mathrm{mL}$. At this $\mathrm{pH}$ level, there was a significant reduction in amount of viable bacteria in biofilm in all three test systems. It was also the only $\mathrm{pH}$ that eradicated all bacteria in the bactericidal biofilm test. Previous studies have shown that $S$. aureus can survive up to a $\mathrm{pH}$ of $9.83(40,41)$. This explains why the TSB control broth $(\mathrm{pH} 9.7)$ and BAG supernatant $(100 \mathrm{mg} / \mathrm{mL}$, primed for $48 \mathrm{~h})(\mathrm{pH} 9.9)$ 
showed no reduction in the amount of viable biofilmassociated bacteria. When the $\mathrm{pH}$ of the TSB control broth was raised to 10.7, five out of eleven strains were eradicated. Supernatant from BAG $400 \mathrm{mg} / \mathrm{mL}$ 48-h priming resulted in a $\mathrm{pH}$ of 10.6 , and three out of eleven strains were eradicated. This finding is in line with previous studies (42) and indicates that high $\mathrm{pH}$ is an important factor against biofilm-associated bacteria.

These in vitro results are promising, but several factors in vivo can affect the clinical response. If the environment around the biofilm does not achieve bactericidal $\mathrm{pH}, \mathrm{S}$. aureus can upregulate a $\mathrm{Na}^{+} / \mathrm{H}^{+}$antiporter system in response to a sudden alkaline shock environment (43). Although further clinical studies are required to explore the antimicrobial effects on biofilm in vivo, this in vitro study indicates that both supernatant and granules of BAG can give bactericidal anti-planktonic and anti-biofilm properties. This reduces the likelihood of recurrent infections after incomplete filling of the bone cavity with BAG $(20,44)$. The tested granules are smaller than the granules typically used in bone packing. Our study suggests that the risk of recurrent infections could possibly be reduced by using small granules, $<45 \mu \mathrm{m}$, which proved to give a more rapid and higher rise in $\mathrm{pH}$. We also showed that the bactericidal effect of BAG is dependent on exposure time and concentration. When BAG has reached its full antimicrobial effect it is as efficient as ciprofloxacin in vitro and could reduce the use of conventional antibiotics where $S$. aureus biofilm is suspected. Our results also suggest that short-term use of antibiotics at the beginning of treatment may be beneficial.

We conclude that BAG-S53P4, $<45 \mu \mathrm{m}$, has powerful antimicrobial effects on $S$. aureus in both planktonic and biofilm states. Duration of exposure and concentration are important factors for achieving maximal effect on biofilm-associated bacteria. Ciprofloxacin may have an additional effect during the first days of treatment.

\section{Acknowledgements}

The authors thank the staff at the Department of Microbiology at the Oslo University Hospital and the Norwegian Veterinary Institute for their excellent support that allowed us to perform the sample analysis in this paper.

\section{Disclosure statement}

The authors have no conflict of interest in the subject matter or materials discussed in this manuscript.

\section{Author contributions}

TG and JTS conceived the study; TG, LKV, LLN, MvU, and JTS conducted research and analysed data; TG wrote the first draft and reviewed it with JTS. All authors contributed to, read, and approved the manuscript.

\section{Funding}

The project was funded by the University of Oslo.

\section{Notes on contributors}

Torstein Grønseth is a consultant at the Department of Otolaryngology, Head and Neck Surgery, Oslo University Hospital, Oslo, Norway and a research fellow at the Institute for Clinical Medicine, University of Oslo, Oslo, Norway.

Lene K. Vestby is Head of Section for immunology and virology, Department of Analysis and Diagnostics at the Norwegian Veterinary Institute. She is also a senior researcher and hold a PhD in bacteriology.

Live L. Nesse, DVM, PhD, Dr.med.vet, is a senior research scientist at the Norwegian Veterinary Institute.

Magnus von Unge, MD, PhD, is a ear surgeon and a professor emeritus at the Department of Clinical Medicine, University of Oslo, Norway.

Juha T. Silvola is a senior consultant in Otology-otoneurology and Audiology in Akershus university hospital (Ahus) and Head for the Research department in the Surgical division of Ahus. In addition, he is an associate professor at the Institute of Clinical Medicine, Campus Ahus, University of Oslo, Norway.

\section{References}

1. Hoiby N. Pseudomonas aeruginosa infection in cystic fibrosis. Diagnostic and prognostic significance of Pseudomonas aeruginosa precipitins determined by means of crossed immunoelectrophoresis. A survey. Acta Pathol Microbiol Scand Suppl. 1977;(262):1-96.

2. DeAntonio R, Yarzabal JP, Cruz JP, Schmidt JE, Kleijnen J. Epidemiology of otitis media in children from developing countries: a systematic review. Int J Pediatr Otorhinolaryngol. 2016;85: 65-74. doi:10.1016/j.ijporl.2016.03.032

3. Percival SL, Hill KE, Williams DW, Hooper SJ, Thomas DW, Costerton JW. A review of the scientific evidence for biofilms in wounds. Wound Repair Regen. 2012;20:647-57. doi:10.1111/j.1524475X.2012.00836.X

4. Burmølle M, Thomsen TR, Fazli M, Dige I, Christensen L, Homøe P, et al. Biofilms in chronic infections - a matter of opportunity monospecies biofilms in multispecies infections. FEMS Immunol Med Microbiol. 2010;59:324-36. doi:10.1111/j.1574-695X.2010. 00714.x

5. Lampikoski H, Aarnisalo AA, Jero J, Kinnari TJ. Mastoid biofilm in chronic otitis media. Otol Neurotol. 2012;33:785-8. doi:10.1097/ MAO.0b013e318259533f

6. Nason R, Chole RA. Bacterial biofilms may explain chronicity in osteoradionecrosis of the temporal bone. Otol Neurotol. 2007;28: 1026-8. doi:10.1097/MAO.0b013e318157f102

7. Lewis K. Persister cells. Annu Rev Microbiol. 2010;64:357-72. doi: 10.1146/annurev.micro.112408.134306

8. Hall-Stoodley L, Stoodley P. Evolving concepts in biofilm infections. Cell Microbiol. 2009;11:1034-43. doi:10.1111/j.1462-5822. 2009.01323.x

9. Nickel JC, Ruseska I, Wright JB, Costerton JW. Tobramycin resistance of Pseudomonas aeruginosa cells growing as a biofilm on urinary catheter material. Antimicrob Agents Chemother. 1985;27: 619-24. doi:10.1128/aac.27.4.619

10. Hall-Stoodley L, Costerton JW, Stoodley P. Bacterial biofilms: from the natural environment to infectious diseases. Nat Rev Microbiol. 2004;2:95-108. doi:10.1038/nrmicro821

11. Singh R, Ray P, Das A, Sharma M. Penetration of antibiotics through Staphylococcus aureus and Staphylococcus epidermidis biofilms. J Antimicrob Chemother. 2010;65:1955-8. doi:10.1093/ jac/dkq257

12. Costerton JW, Lewandowski Z, Caldwell DE, Korber DR, LappinScott HM. Lappin-Scott HM. Microbial biofilms. Annu Rev Microbiol. 1995;49:711-45. doi:10.1146/annurev.mi.49.100195. 003431

13. Liñares J, Ardanuy C, Pallares R, Fenoll A. Changes in antimicrobial resistance, serotypes and genotypes in Streptococcus pneumoniae 
over a 30-year period. Clin Microbiol Infect. 2010;16:402-10. doi: 10.1111/j.1469-0691.2010.03182.x

14. Moxnes JF, de Blasio BF, Leegaard TM, Moen AE. Methicillin-resistant Staphylococcus aureus (MRSA) is increasing in Norway: a time series analysis of reported MRSA and methicillin-sensitive $\mathrm{S}$. aureus cases, 1997-2010. PLoS One. 2013;8:e70499. doi:10.1371/journal. pone.0070499

15. Drago L, Toscano M, Bottagisio M. Recent evidence on bioactive glass antimicrobial and antibiofilm activity: a mini-review. Materials 2018;11:326. doi:10.3390/ma11020326

16. Coraca-Huber DC, Fille M, Hausdorfer J, Putzer D, Nogler M. Efficacy of antibacterial bioactive glass S53P4 against $\mathrm{S}$. aureus biofilms grown on titanium discs in vitro. J Orthop Res. 2014;32: 175-7. doi:10.1002/jor.22463

17. van Gestel NA, Geurts J, Hulsen DJ, van Rietbergen B, Hofmann S, Arts JJ. Clinical applications of S53P4 bioactive glass in bone healing and osteomyelitic treatment: a literature review. Biomed Res Int. 2015;2015:684826. doi:10.1155/2015/684826

18. Baino F, Hamzehlou S, Kargozar S. Bioactive glasses: where are we and where are we going? JFB. 2018;9:25. doi:10.3390/jfb9010025

19. Kluge A, Neudert M, Kunert-Keil C, Lailach $S$, Zahnert T, Kemper $M$. The obliteration of noncritical size bone defects with bone dust or bone replacement material (bioactive glass S53P4). Otol Neurotol. 2019;40:e415-23. doi:10.1097/MAO.0000000000002178

20. Lindfors NC, Hyvönen $P$, Nyyssönen $M$, Kirjavainen M, Kankare J, Gullichsen E, et al. Bioactive glass S53P4 as bone graft substitute in treatment of osteomyelitis. Bone 2010;47:212-8. doi:10.1016/j. bone.2010.05.030

21. Peltola M, Aitasalo K, Suonpää J, Varpula M, Yli-Urpo A. Bioactive glass S53P4 in frontal sinus obliteration: a long-term clinical experience. Head Neck. 2006;28:834-41. doi:10.1002/hed.20436

22. Sarin J, Grenman R, Aitasalo K, Pulkkinen J. Bioactive glass S53P4 in mastoid obliteration surgery for chronic otitis media and cerebrospinal fluid leakage. Ann Otol Rhinol Laryngol. 2012;121:563-9. doi:10.1177/000348941212100901

23. Silvola JT. Mastoidectomy cavity obliteration with bioactive glass: a pilot study. Otolaryngol Head Neck Surg. 2012;147:119-26. doi: 10.1177/0194599812438168

24. Hakanen A, Huovinen P, Kotilainen P, Siitonen A, Jousimies-Somer H. Quality control strains used in susceptibility testing of Campylobacter spp.J Clin Microbiol. 2002;40:2705-6. doi:10.1128/ jcm.40.7.2705-2706.2002

25. Masadeh MM, Mhaidat NM, Alzoubi KH, Hussein El, Al-Trad El. In vitro determination of the antibiotic susceptibility of biofilm-forming Pseudomonas aeruginosa and Staphylococcus aureus: possible role of proteolytic activity and membrane lipopolysaccharide. Infect Drug Resist. 2013;6:27-32. doi:10.2147/IDR.S41501

26. Munukka $E$, Leppäranta $O$, Korkeamäki $M$, Vaahtio $M$, Peltola $T$, Zhang $D$, et al. Bactericidal effects of bioactive glasses on clinically important aerobic bacteria. J Mater Sci Mater Med. 2008;19:27-32. doi:10.1007/s10856-007-3143-1

27. Massias L, Buffe P, Cohen B, Cudennec Y, Gehanno P, Sterkers O, et al. Study of the distribution of oral ciprofloxacin into the mucosa of the middle ear and the cortical bone of the mastoid process. Chemotherapy 1994;40:3-7. doi:10.1159/000239309

28. Wiegand I, Hilpert K, Hancock RE. Agar and broth dilution methods to determine the minimal inhibitory concentration (MIC) of antimicrobial substances. Nat Protoc. 2008;3:163-75. doi:10.1038/ nprot.2007.521

29. Stepanović S, Vuković D, Hola V, Di Bonaventura G, Djukić S, Cirković l, et al. Quantification of biofilm in microtiter plates: overview of testing conditions and practical recommendations for assessment of biofilm production by staphylococci. Apmis. 2007; 115:891-9. doi:10.1111/j.1600-0463.2007.apm_630.x

30. Moussa SH, Tayel AA, Al-Hassan AA, Farouk A. Tetrazolium/formazan test as an efficient method to determine fungal chitosan antimicrobial activity. J Mycol. 2013;2013:1-7. doi:10.1155/2013/ 753692

31. Tengerdy RP, Nagy JG, Martin B. Quantitative measurement of bacterial growth by the reduction of tetrazolium salts. Appl Microbiol. 1967;15:954-5.

32. Pérez LM, Alvarez BL, Codony F, Fittipaldi $M$, Adrados B, Peñuela $G$, et al. A new microtitre plate screening method for evaluating the viability of aerobic respiring bacteria in high surface biofilms. Lett Appl Microbiol. 2010;51:331-7. doi:10.1111/j.1472-765X.2010. 02902.x

33. Junka A, Bartoszewicz M, Smutnicka D, Secewicz A, Szymczyk P. Efficacy of antiseptics containing povidone-iodine, octenidine dihydrochloride and ethacridine lactate against biofilm formed by Pseudomonas aeruginosa and Staphylococcus aureus measured with the novel biofilm-oriented antiseptics test. Int Wound J. 2014;11:730-4. doi:10.1111/iwj.12057

34. Grønseth T, Vestby LK, Nesse LL, Thoen E, Habimana O, von Unge $M$, et al. Lugol's solution eradicates Staphylococcus aureus biofilm in vitro. Int J Pediatr Otorhinolaryngol. 2017;103:58-64. doi:10. 1016/j.ijporl.2017.09.025

35. Mah TF. Establishing the minimal bactericidal concentration of an antimicrobial agent for planktonic cells (MBC-P) and biofilm cells (MBC-B). J Vis Exp 2014;(83):e50854. doi:10.3791/50854

36. Zenga J, Gagnon PM, Vogel J, Chole RA. Biofilm formation by otopathogenic strains of Pseudomonas aeruginosa is not consistently inhibited by ethylenediaminetetraacetic acid. Otol Neurotol. 2012 33:1007-12. doi:10.1097/MAO.0b013e31825f249e

37. Wang EW, Agostini G, Olomu O, Runco D, Jung JY, Chole RA. Gentian violet and ferric ammonium citrate disrupt Pseudomonas aeruginosa biofilms. Laryngoscope. 2008;118:2050-6. doi:10.1097/ MLG.0b013e3181826e24

38. Araújo PA, Mergulhão $F$, Melo L, Simões $M$. The ability of an antimicrobial agent to penetrate a biofilm is not correlated with its killing or removal efficiency. Biofouling 2014;30:675-83. doi:10. 1080/08927014.2014.904294

39. Stoor P, Söderling E, Salonen Jl. Antibacterial effects of a bioactive glass paste on oral microorganisms. Acta Odontol Scand. 1998;56: 161-5. doi:10.1080/000163598422901

40. Smolka LR, Nelson FE, Kelley LM. Interaction of $\mathrm{pH}$ and $\mathrm{NaCl}$ on enumeration of heat-stressed Staphylococcus aureus. Appl Microbiol. 1974;27:443-7.

41. Genigeorgis C, Foda MS, Mantis A, Sadler WW. Effect of sodium chloride and $\mathrm{pH}$ on enterotoxin $\mathrm{C}$ production. Appl Microbiol. 1971;21:862-6.

42. Allan I, Newman H, Wilson M. Particulate Bioglass reduces the viability of bacterial biofilms formed on its surface in an in vitro model. Clin Oral Implants Res. 2002;13:53-8. doi:10.1034/j.16000501.2002.130106.x

43. Anderson $\mathrm{KL}$, Roux $\mathrm{CM}$, Olson $\mathrm{MW}$, Luong $\mathrm{TT}$, Lee $\mathrm{CY}$, Olson $\mathrm{R}$, et al. Characterizing the effects of inorganic acid and alkaline shock on the Staphylococcus aureus transcriptome and messenger RNA turnover. FEMS Immunol Med Microbiol. 2010;60:208-50. doi: 10.1111/j.1574-695X.2010.00736.x

44. Romanò $\mathrm{CL}$, Logoluso $\mathrm{N}$, Meani $\mathrm{E}$, Romanò $\mathrm{D}$, De Vecchi $\mathrm{E}$, Vassena $C$, et al. A comparative study of the use of bioactive glass S53P4 and antibiotic-loaded calcium-based bone substitutes in the treatment of chronic osteomyelitis: a retrospective comparative study. Bone Joint J. 2014;96-B:845-50. doi:10.1302/0301-620X. 96B6.33014 